\title{
Uma mulher educada no oitocentos: a escrita feminina no Diário da Viscondessa de Arcozelo
}

\author{
Maria Celi Chaves Vasconcelos \\ Universidade do Estado do Rio de Janeiro
}

\section{Resumo}

O artigo trata da educação feminina no Brasil oitocentista, com foco no Diário de Lembranças escrito pela Viscondessa de Arcozelo, durante o ano de 1887. O objetivo refere-se à análise dessa fonte documental para recompor a educação considerada adequada a uma mulher nobre e que exercia as funções esperadas de sua posição social. O referencial teórico utilizado remete aos estudos de Lejeune (1997) e Nora (1989), assim como aos escritos de Barbalato (2014), Gómez (2014), Vasconcelos (2014) e Cunha (2011). Os resultados revelam traços representativos de uma mulher educada "no" e "para" o oitocentos e como enfrentava os desafios do seu tempo.

Palavras-chave: Viscondessa de Arcozelo. Diário de lembranças. Educação feminina.

\section{A woman educated in the nineteenth-century: woman's writing in the Viscountess of Arcozelo's Diary}

\section{Abstract}

The article focuses on woman's education in nineteenth-century Brazil, based on the Diary of Memories written by the Viscountess of Arcozelo, during 1887. The objective is the analysis of this documentary source to restore what was considered appropriated education to a noble woman, who exercised the expected functions of their social position. The theoretical framework refers to Lejeune (1997) and Nora's (1989) studies, and the writings of Barbalato (2014), Gomez (2014), Vasconcelos (2014) and Cunha (201 1). The results reveal representatives features of an educated woman "in" and "for" the eighteen hundreds, and their way to face the challenges of that time.

Keywords: Viscountess of Arcozelo. Diary of Memories. Women's education. 


\section{Una mujer educada en ochocientos: escritura femenina en lo Diario de la Vizcondesa de Arcozelo}

\section{Resumen}

El artículo se centra en la educación femenina en el siglo XIX Brasil, con base en lo Diario de Recuerdos escrito por la Vizcondesa de Arcozelo, durante el año 1887. El objetivo es el análisis de esta fuente documental para restaurar la educación considerada apropiada para una mujer noble, y que ejercía funciones que se esperan de su rango. El marco teórico se refiere a los estudios de Lejeune (1997) y Nora (1989), y a los escritos de Barbalato (20 14), Gómez (20 14), Vasconcelos (20 14 ) y Cunha (201 1). Los resultados ponen de manifiesto rastros representativos de una mujer educada "en" y "para" los ochocientos y cómo hacia frente a los desafíos de su tiempo. Palabras clave: Vizcondesa de Arcozelo. Diario de Recuerdos. La educación de las mujeres.

\section{A arqueologia de um encontro: o Diário de Lembranças}

De acordo com Philippe Lejeune (1997), pesquisador que conduziu uma investigação sobre diários de garotas francesas no século XIX, os diários femininos que datam desse período encontram-se entre as fontes documentais consideradas de difícil acesso, por estarem, normalmente, com descendentes ou em coleções particulares, o que inviabiliza a socialização de seu conteúdo a estudos ampliados. No que se refere ao Brasil, Gillies (2013) faz a mesma constatação em seu estudo sobre o diário de Caroline Tamplin, no qual ressalta a existência das "fogueiras" que livravam as famílias de velhos papéis guardados, cujo conteúdo não interessava as novas gerações.

Excetuando-se os diários já impressos, a grande maioria dos egodocumentos datados do século XIX e início do século XX, ainda está em seu estado original, manuscrito, sob a guarda de alguma instituição ou de uma coleção privada.

Esse contexto caracteriza a singularidade e raridade da aparição de documentos como os diários íntimos, conceituados por Cunha (2000; 2011 1), como aqueles que proporcionam aos historiadores muitas das maneiras de rastrear os modos de viver e de pensar de determinada época, uma vez que cada existência possui constatada similaridade com outras de seu tempo, 
especialmente as que apresentam a mesma condição social e as mesmas expectativas em relação à realidade.

Não obstante a escassez de tais fontes, o Museu Imperial de Petrópolis guarda um representante incomum desses egodocumentos, o Diário de Lembranças, escrito pela Viscondessa de Arcozelo, uma mulher cujo título nobiliárquico era a sua assinatura pessoal, elaborado ao longo do ano de 1887, quando, em cada página, são registrados os principais fatos ocorridos no seu cotidiano.

$\bigcirc$ Diário de Lembranças chegou ao Museu Imperial de Petrópolis em 26 de dezembro de 1994', doado a essa instituição por Ligia Werneck de Castro Souza Marques, neta da Viscondessa, conforme registrado no documento de doação e anotado no livro de memórias escrito por Maria Werneck de Castro (2004). Lá ficou adormecido nas prateleiras, poucas vezes solicitado, até chamar a atenção de historiadores como Mauad e Muaze (2004) que, ao compará-lo com outras fontes documentais, entre elas os relatos de viajantes, concluem que essa "escrita da intimidade" torna-se uma chave para a recomposição de aspectos do cotidiano, que não são facilmente encontrados em escritos com a finalidade de registros e para serem lidos por outros.

106 Afirmam as autoras:

Ao se ler o diário da viscondessa do² Arcozelo, que se encontra no Museu Imperial de Petrópolis, e outras narrativas escritas por brasileiros pertencentes à boa sociedade, principalmente a documentação íntima, fica a clara sensação de descompasso entre as duas maneiras de narrar o cotidiano. De um lado, as narrativas dos viajantes, escritas para registrar, mas também para tornar pública a opinião postulada por alguém que se considerava um especialista, operam com a chave de leitura clássica do período - civilização versus barbárie. De outro, as escritas da intimidade, que revelam um cotidiano repleto de estratégias de sociabilidade e convivência num ambiente permeado pela diferença social, pela tensão de classe e pela luta continuada por manter a riqueza num mundo em transformação (MAUAD; MUAZE, 2004, p. 199).

Além das múltiplas leituras possiveis de se depreender do Diário de Lembranças, emergem ainda outras interpretações sobre a condição feminina da autora e a educação que deverá ter recebido, demonstrada não apenas no hábito cultivado de escrever um diário íntimo, mas também na formação que 
é evidenciada nos relatos de sua atuação social, de acordo com aquilo que era esperado de uma mulher nobre, dona de fazendas no Vale do Paraíba e senhora de cerca de mil escravos ${ }^{3}$.

Nessa perspectiva, o objetivo central do estudo refere-se à análise do Diário de Lembranças, como fonte documental para recompor a educação considerada adequada a uma mulher nobre e que exercia as funções esperadas de sua posição social, além dos atributos esperados da "boa educação feminina" (VASCONCELOS, 2005), praticada nesse tempo e contexto.

O referencial teórico central reside nos escritos de Lejuene (1997), do qual se adota a concepção de diário íntimo, essencialmente de "crônicas", que é utilizada para classificar a escrita da Viscondessa. Com base nas análises desse autor, pode-se afirmar que, no Diário de Lembranças da Viscondessa:

[...] são feitos registros do dia-a-dia, nos quais as anotações limitam-se aos eventos externos da vida cotidiana, poucas vezes sendo possível adiantar seus sentimentos ao escrever, embora isso ocorra em momentos que expressa sua tristeza, compaixão, ciúme, aborrecimento e até rancor diante das situações que vivencia (VASCONCELOS, 2014, p. 103).

Embora subjetivo em relação aos sentimentos de sua autora, o Diário de Lembranças é essencial para a leitura do contexto vivido, especialmente do que se esperava e se praticava, tratando-se de uma mulher de elite educada para exercer um papel social bem demarcado no período quando o egodocumento foi escrito.

Já na perspectiva da historicidade do Diário de Lembranças, Pierre Nora (1987, p. 351-355) contribui com a ideia de "ego-história", demonstrando que toda a história de vida é também uma história que permite múltiplas entradas, desde o particular ao "valor genérico", sendo possível fazer da história de si "[...] uma curiosidade nativa e a exploração crítica de uma série de imagens íntimas".

É a partir da exploração das imagens íntimas descritas pela Viscondessa em seu diário de crônicas que o contexto de uma época, a rede de sociabilidade existente entre as famílias, suas crenças, seus temores, seu senso estético, as aspirações permitidas e negadas, podem ser parcialmente desveladas, e, nelas, um elemento se destaca: a educação recebida, já que está implícita, na origem dos conceitos, preconceitos, valores e atitudes 
descritos. Destarte, a Viscondessa movimenta-se e registra seu cotidiano com base nos procedimentos e conhecimentos considerados adequados à formação feminina para o desempenho daquilo que era esperado das mulheres de condição semelhante a sua: ser boa mãe, boa gestora da casa e uma esposa atenta às determinações do marido. No Diário de Lembranças, a Viscondessa demonstra, detalhadamente, em diversas circunstâncias descritas, exemplos da forma como interpretou essas lições.

Todavia, cabe lembrar, segundo Barbalato (2014, p. 29, 53) sugere "[...] o longo tormento do homem em busca de uma imagem desejada [...]", ou seja, embora se trate de uma escrita íntima para a qual não se esperavam interlocutores, não é possível identificar até onde a mesma não está impregnada da construção de uma personagem censurada pelo registro escrito. Ainda assim, tomando os estudos da mesma autora citando Nietzsche, o que importa no presente artigo é a noção contida na "[...] célebre epígrafe em Ecce homo 'Como se torna o que se é'".

Ao recompor alguns aspectos da vida da Viscondessa, especialmente no que refere aos efeitos que a educação feminina recebida naquele tempo e contexto trouxe para o seu cotidiano, cabe, também, voltar-se para os limites 108 impostos ao trabalho com egodocumentos. Para tanto, vale ressaltar o que Antonio Castillo Gómez (2014, p. 61) denomina de egodocumento, "[...] textos en los que un autor escribe sobre sus propios actos, pensamientos y sentimientos $[\ldots]^{14}$, chamando atenção para um aspecto essencial contido nessas fontes, que são as estratégias empregadas pelos autores com o objetivo de dar verossimilhança à narrativa, ou seja, aquilo que Philippe Lejeune lapud GÓMEZ, 2014 , p. 65 e 66), denomina de "contrato de veracidad" ou "pacto de verdad", "[...] pues todo diario tiene un destinatario, aunque este sea uno mismo".

Para quem a Viscondessa escrevia, além de si mesma, e com que propósito, é algo que dificilmente será elucidado, contudo, certo é que o Diário de Lembranças, embora visivelmente censurado pela própria autora, contém indícios que sinalizam como nenhuma outra fonte é capaz de fazê-lo, o momento instantâneo da memória cotidiana, estampado nas páginas escritas. Ainda que também padeça tanto do defeito de construção de uma personagem, como do explícito desejo de pactuar uma verdade, a forma como ambas as estratégias são utilizadas se tornam suficientes para cercar o objeto de estudo, nesse caso, a educação feminina considerada referência de uma época. 
Por fim, ao ler o Diário de Lembranças da Viscondessa de Arcozelo em busca de aspectos de sua formação que evidenciem a educação recebida, seja em colégios femininos, seja através de preceptoras e professores particulares, deve-se ter o cuidado essencial ao pesquisador de, ao remexer nas escritas íntimas, considerar as expectativas, medos, angústias e contentamentos expressos em palavras, compreendendo a impossibilidade de recompor a totalidade do cenário e do sentido do que está escrito.

\section{O "utilíssimo livro" de Antônio José Gomes Brandão: um agradecimento aos "cavalheiros"}

Diário de Lembranças da Viscondessa de Arcozelo é um livro de capa dura, no formato e tamanho de uma agenda de mesa moderna, com uma encadernação verde encapada com papel marmorizado. $\bigcirc$ nome do editor "Brandão" aparece ladeando as palavras "Diário de Lembranças" e o ano de 1887. A contracapa traz a folhinha para o primeiro semestre do ano de 1887, sendo indicado que o segundo semestre está no fim do livro. Vale notar que a folhinha contém duas informações associadas às datas, as fases da lua e os santos padroeiros de cada dia, parecendo ser essas as informações relevantes para o acompanhamento dos dias da semana. Ao final da página, já acrescentando mais nomes a sua assinatura, Gomes Brandão informa que o livro foi produzido em sua tipografia e se refere a si próprio como um comerciante de papel e de livros.

A página seguinte é a folha de rosto propriamente, na qual o editor, finalmente, se apresenta com o nome completo Antônio José Gomes Brandão e descreve a sua publicação como 365 páginas para notas diárias, contendo:

Relação alphabetica das estações das estradas de ferro nas províncias do Rio de Janeiro, Minas e São Paulo; Itinerário dos bondes da companhia - Carris Urbanos; - Folhinha e avisos para pagamentos de impostos; Annuncios de companhias e estabelecimentos commerciaes importantes. - $4^{\circ}$ ANNO - Vende-se em casa do editor-proprietario A. J. Gomes Brandão 90, Rua da Quitanda, 90 - Rio de Janeiro (VISCONDESSA DE ARCOZELO, 1887, s/p.).

A seguir, a página contém o desenho de uma pequena prensa com as iniciais do editor na base e objetos de tipografia, ladeados pelas palavras 
"diário e razão." Abaixo, com tipos gráficos diferenciados, consta a informação de que "vende-se em casa do editor-proprietário", no número 90 da Rua da Quitanda, Rio de Janeiro.

Antônio José Gomes Brandão parece ter sido um bem-sucedido comerciante de papel e livros, como ele mesmo se apresenta, considerando ter a sua própria tipografia e estar estabelecido num ponto central da Rua da Quitanda, endereço de efervescência do comércio carioca na época, últimas décadas do século XIX. Embora a casa comercial de Antônio Brandão não esteja mencionada no livro de Ernesto Senna, $O$ velho comércio do Rio de Janeiro, originalmente publicado pela livraria Garnier, em 1910, é muito provável que o comerciante convivesse com os estabelecimentos citados por esse autor (SENNA, 2006), pois o cabeçalho de cada um dos dias do diário/ agenda do ano de 1887, criado por Antônio Brandão, continha um anúncio, entre os quais se podem localizar vários dos estabelecimentos eternizados por Senna (2006), como sendo as "antigas casas comerciais desta cidade" e seus proprietários. Seguramente, Antônio Brandão privou da amizade ou, pelo menos, de relações comerciais com alguns deles, tendo em vista constarem como anunciantes de sua publicação. A Euterpe, Cardoso \& C., por

110 exemplo, é a anunciante do cabeçalho de $1^{\circ}$ de fevereiro, com a indicação do endereço Rua da Quitanda, número 86, o que significa estar localizada muito próxima ao estabelecimento de Antônio Brandão, cujo anúncio no diário é assim escrito:

No Império do Brasil é este o maior, o mais antigo e o mais acreditado estabelecimento de instrumentos de música, physica, engenharia, optica, objetos para igreja, para dentistas, inclusive - Manual do Dentista, de sua edição e tudo que são miudezas e accessorios relativos (VISCONDESSA DE ARCOZELO, 1887, s/p.).

De acordo com Senna (2006), a casa de Cardoso \& C. era um dos mais antigos negócios comerciais no Rio de Janeiro, especializado em instrumentos de música, de ótica e de material para dentistas, remontando a sua fundação ao ano de 1867, o que oferece uma ideia da vizinhança comercial de Antônio Brandão.

Ao concentrar a análise apenas nos anunciantes presentes no cabeçalho do diário no mês de fevereiro, pode-se constatar outra prática constante 
de Antônio Brandão, a de anunciar os seus próprios produtos, ou seja, do dia 8 de fevereiro em diante, distribuindo-se pelos dias seguintes, o comerciante anuncia a venda de diversos produtos em sua loja, entre eles, talões impressos de recibos de dinheiro e de alugueis de prédios, procurações para negociantes matriculados e para tabeliães, álbuns para retratos de várias formas e encadernações "sortidas", "variadíssimo" sortimento de envelopes, estojos de compassos, réguas, esquadros, tintas e papel para desenho, "extraordinário" sortimento de tinteiros para escritórios, secretarias e viagens, impressão de relatórios e qualquer obra "com brevidade", livros portugueses, latinos, franceses e ingleses para instrução, conhecimentos e despachos impressos, calendários com espaços para tomar notas, produtos que afirma como uma "especialidade da casa". São oferecidas ainda cartas de convites para enterros e para assistir a missas de finados, livros para escrituração com traços especiais e dísticos impressos nas páginas, calendários de esfolhear e folhinhas para o ano corrente, pastas para escritórios de vários formatos e qualidades, cartões de visita e casamentos com envelopes e "obras de aliança", carteiras para dinheiro e livros de algibeira para lembranças; assim como também é anunciada a informação: "Encarrego-me de enviar para o interior as mercadorias do meu comércio."

Como se observa, a loja de Antônio Brandão possuía um estoque, capaz de preencher os cabeçalhos, com praticamente todos os anúncios do mês de fevereiro, a partir do dia 8, entremeados apenas pelas "roupas de superior qualidade e baratíssimas para as próximas festas de carnaval", anunciadas pela Imperial Alfaiataria Águia de Ouro, situada na Rua do Hospício, número 92.

estoque da casa comercial de Antônio Brandão e dos demais anunciantes descritos em cada página do diário, quando analisados em suas minúcias, mostram a primeira leitura que a Viscondessa fazia ao tomar o diário para registrar os acontecimentos, assim como revelam a materialidade que compunha o contexto em que ela vivia. Papéis de cartas, envelopes, convites, impressos, álbuns, tinteiros, fantasias de carnaval, objetos que, de alguma forma, estavam presentes na vida que se passava nas fazendas de sua propriedade no interior da Província do Rio de Janeiro, ao alcance da Viscondessa, provavelmente, por conta do serviço de entregas que Antônio Brandão mantinha, como ele mesmo anunciava. Tal suposição deve-se ao fato de que, embora a Viscondessa tenha registrado uma constante ligação com 
a Corte, assim como a sua permanência na cidade durante alguns períodos, por diversas vezes, também demonstra ter feito uso de encomendas a casas comerciais, especialmente quando ela anota, detalhadamente, em seu Diário de Lembranças, a chegada dos produtos.

Muito se pode depreender da análise material de cada uma das folhas do livro publicado como Diário de Lembranças por Antônio Brandão, mas alguns aspectos são centrais para este estudo, entre eles, que havia um público feminino suficientemente fiel ao consumo desse tipo de caderno de anotações, tendo em vista se tratar do quarto ano de sua publicação.

Não resta dúvida de que o público principal era constituído por mulheres, pois não se supõe que o Diário de Lembranças fosse endereçado aos homens oitocentistas, mas chama atenção o fato de que é "aos cavalheiros" que o editor agradece no final do livro:

Atenção: Agradeço aos cavalheiros que me auxiliaram, com annuncios, a publicação deste utilíssimo livro, esperando que mantenham a mesma benevolência para as edições futuras, as quaes ainda serão melhoradas se o respeitável público, atender ao diminuto preço estabelecido, a qualidade do papel e o valor dos annexos. Peço as pessoas que se dignaram mandar comprar este livro o obséquio de recommendar que comprem o Diario de Lembranças de A. Brandão, O Edictor (VISCONDESSA DE ARCOZELO, 1887, $s /$ p.).

Provavelmente, a referência aos cavalheiros, além dos anunciantes, englobasse também os maridos que adquiriam o livro para as suas mulheres, que, em regra, deveriam ser os mesmos consumidores de outras publicações que tomavam vulto na Corte brasileira no final da década de 1880, tanto para a sua própria leitura, como para presentear irmãs, filhas e esposas. No que concerne à educação feminina, para tornar as mulheres boas esposas, mães de família e gestoras da casa, esses preceitos estavam expostos em diversos manuais que, segundo Malta (201 1, p. 42), eram publicados para a organização do lar ou da economia doméstica, "[...] pois era preciso preparar as futuras rainhas para ocuparem seu reino". De acordo com a autora, desde o período Imperial, os folhetins e os romances já se dedicavam a assuntos sobre o asseio e a ordem do lar, a educação dos filhos, o orçamento familiar e o trato com os empregados, tentando convencer as leitoras "[...] da responsabilidade 
do papel de mãe e esposa na formação do caráter e da saúde da nação" (MALTA, 2011 , p. 43-44).

Antônio Brandão, certamente, devia estar atento a essas publicações, uma vez que seu diário contém grande parte dos anúncios direcionados ao público feminino, relativos à economia doméstica da casa, à escolha entre os colégios existentes para quem podia pagar por seus serviços, a objetos de leitura e escrita que, do mesmo modo, dirigiam-se ao público que lia e consumia material de papelaria, ou anúncios que, simplesmente, destinavam-se a estimular o consumo de artigos supérfluos que se tornavam cada vez mais desejados pelas mulheres oitocentistas. De acordo com Vasconcelos:

Após a terceira capa, as 365 páginas correspondentes a cada dia do ano são encimadas por anúncios os mais diversos, como os de biscoitos em latas, companhias de seguros, casa de leques e luvas, lojas de pianos e músicas, lojas de tecidos, vestidos, paletós, capas, enxovais, 'fazendas grossas para os escravos', impressões de cartões de visita e de casamento, colégios, externatos e internos, casa de calçados, drogarias, propaganda de unguentos, máquinas de costura, advogados, cartões de visita, livros, álbuns de retratos, papéis, envelopes, compassos, réguas, tintas, alfaiates, convites para missas e enterros, entre muitos outros (VASCONCELOS, 2014, p. 102).

Contudo, a variedade de produtos e incorporação do público feminino como alvo de muitas casas comerciais não significava que as mulheres transitassem livremente pelas ruas do Ouvidor ou da Quitanda, ainda que essas fossem bastante movimentadas. A saída das mulheres às ruas, na década de 1880, já não era mais como a descrita por Senna (2006, p. 22), referindo-se aos idos de 1835, quando "[...] a família levava vida claustral [...] e era raro [...] que as mulheres e os menores fossem às lojas e aos armazéns escolher e prover-se do que desejassem ter [...]", mas ainda guardava elementos de um ritual para a ida das mulheres às casas comerciais, o que acontecia, notadamente, estando acompanhadas e em horários específicos.

Tais hábitos começam a ser mudados pela presença maciça de estrangeiros, especialmente as mulheres, que nem sempre se submetiam às convenções sociais brasileiras e essas, a julgar pelas funções e posições que ocupavam, em uma sociedade que valorizava tudo o que vinha do exterior, acabavam por influenciar particularmente as classes sociais mais elevadas, 
como era o caso da Viscondessa. Embora acompanhada por parentes e sempre, no mínimo, por dois escravos, a Viscondessa fazia viagens para outras cidades e transitava na Corte com certa desenvoltura, hospedando-se em hotéis, mandando buscar "fora" o seu jantar, fazendo visitas em casa de parentes e amigos e realizando pequenas compras por onde passava, detalhadamente descritas no Diário, assim como as gorjetas que ofertava.

Antônio Brandão e seus anunciantes, certamente, foram participes de um período quando as mulheres começaram a ser reconhecidamente estimuladas como consumidoras e leitoras no Rio de Janeiro oitocentista, ainda que essa propaganda não tenha atingido a toda população feminina, mas apenas a uma parcela que, entre outras coisas, era usuária de publicações como - Diário de Lembranças. Para grave infortúnio, até o presente, dos quatro anos ininterruptos e testemunhados da publicação do Diário de Lembranças de Antônio Brandão, somente um exemplar, escrito por uma de suas endereçadas, chegou até os nossos dias.

\section{Uma história vivida e registrada: a Viscondessa e o seu contexto}

Como todas as histórias, a vida da Viscondessa de Arcozelo, nascida Maria Isabel de Lacerda Werneck, tem começo, meio e fim. Entretanto, nessa história, aquilo que era considerado o bom, o belo, a plenitude de uma vida feminina no século XIX, está singularmente representado no começo e meio dessa história.

Maria Isabel de Lacerda Werneck era filha do Barão de Pati do Alferes, um dos mais representativos fazendeiros do café de seu tempo, que exerceu o poder na sua região e na Corte, comandando, inclusive, a Guarda Nacional contra os escravos aquilombados, em 1836, o que significava, por si só, uma condição honrosa para toda a família (MUNIZ, 2005).

Ainda de acordo com Muniz (2005), a mãe da Viscondessa, a Baronesa Maria Isabel Ribeiro de Avelar, era filha de uma das mais antigas famílias do Vale do Paraíba, considerada como o tronco genealógico que deu origem ao povoamento de Vassouras, e com o qual estreitaram laços familiares, pelo menos, três representantes da nobreza imperial, o Barão de Guaribú, o Barão de Capivary, e o Visconde de Ubá. 
Com esse princípio de história é natural se compreender a Viscondessa como uma mulher de seu tempo, nascida e criada para as principais aspirações femininas da época: honrar a família, casar dentro das expectativas dos pais e comportar-se de acordo com os títulos de nobreza recebidos, naquilo que tangia a uma mulher da aristocracia brasileira (e, neste caso, portuguesa também, pois o título de Visconde de Arcozelo foi concedido a seu marido, Joaquim Teixeira de Castro, em 1874, pelo Rei de Portugal, D. Luis I, referindo-se à vila onde $\mathrm{V}$ Visconde nasceu $)^{5}$.

Ser uma mulher nascida na elite cafeeira exigia uma educação esmerada, porém exclusivamente voltada para a gestão da casa, agradar ao marido, criar "bem" os filhos e incumbir-se da liderança sobre um bataIhão de escravos e escravas que povoavam o cotidiano das casas, sedes das fazendas, ou da Corte. Este era o cenário por onde transitavam essas mulheres imersas em seus problemas cotidianos e domésticos, que, embora aparentem, por vezes, revelar uma vida tranquila, eram capazes de preencher uma agenda, com atividades femininas obrigatórias e permitidas, durante quase todos os dias do ano, como se percebe ao ler o diário da Viscondessa de Arcozelo, no ano de 1887.

Embora esse começo, cercado daquilo que existia em termos de riqueza e poder no Brasil oitocentista, permita supor uma vida repleta das possibilidades femininas para a elite, naquele tempo e lugar, a Viscondessa reflete, em sua história de vida, a própria história do país, e o seu fim acompanha o fim de uma era, em que não apenas mudanças políticas, econômicas e sociais ocorreram, mas toda uma lógica, um estilo e uma estética foram transformados, fazendo personagens, outrora vencedores, tornarem-se vencidos, deixando a história dos grandes nomes e feitos, para ingressar na história dos anônimos.

Assim, referindo-se ao ano de 1912, a neta Maria Werneck de Castro, em seu livro No tempo dos Barões (2004), conta a morte da avó, a quem intitula como A Viscondessa Pobre. Segundo ela, o enterro da Viscondessa de Arcozelo, quando morreu, "foi de pobre" (CASTRO, 2004). $\bigcirc$ caixão, "[... ] carregado pelos ex-escravos maltrapilhos, descalços, de chapéu na mão, um a um [...]", foi transportado num carro de bois a caminho do cemitério de Pati do Alferes (CASTRO, 2004, p. 70). A neta registra, com descrença, que a pobreza da Viscondessa e de seus filhos era tanta, que a família da zeladora do cemitério é que pagou o enterro. Além disso, a herança recebida pela descendente resumia-se a "lembranças de vovó", como miniaturas de um boneco 
preto, uma ânfora de metal e um botão amarelo destinado a sua prima, descritos pela autora como "coisas de pobre".

Lendo o diário da Viscondessa, apenas em sua escrita literal, sem considerar o contexto em ebulição que caracterizou o final da década de 1880, é difícil presumir o fim dessa mulher pertencente aos principais quadros da nobreza brasileira. Parecendo, ou devendo parecer, muitas vezes, alheia ao que se passava, preocupada com os seus próprios afazeres, com as obrigações de gestora da casa e colocando em prática os ensinamentos recebidos como uma mulher educada de elite, ela não faz referência aos importantes negócios que se desfaziam e refaziam nesse mesmo ano, 1887, como a dissolução da sociedade Teixeira de Castro \& Malafaia, entre o Visconde de Arcozelo e um de seus sócios Luiz de Malafaia, quando o marido e o filho, Ernesto Werneck Teixeira de Castro, decidem continuar sozinhos o negócio da Casa Comissária de Café, que possuíam na Corte (MUNIZ, 2005).

Todavia, é preciso observar que, de alguma forma, a Viscondessa, apesar de distante dos negócios que contribuiriam para o seu final empobrecido entre os escravos já libertos, mas ainda cativos de qualquer perspectiva, demonstra não estar totalmente alheia às preocupações masculinas do oito116 centos. Ao longo de todo o ano quando realizou as suas anotações, revela, ininterruptamente, uma constante preocupação com as condições atmosféricas. Já na segunda frase escrita no seu diário, no primeiro dia de janeiro de 1887, se refere à chuva, que teria caído "fortemente" à tarde. A partir daí, cotidianamente, a Viscondessa registra a sua preocupação com as chuvas, demonstrando que, embora não compartilhasse a discussão dos negócios masculinos, sabia que as condições pluviométricas tinham consequências diretas sobre o plantio do café, matéria-prima e origem da riqueza da família.

É ingênuo pensar que tais registros, recorrentes, tratariam unicamente, dos lamentos de uma mulher queixando-se do mau tempo com o seu confidente íntimo, o diário. Ao contrário, as condições meteorológicas são uma das principais anotações da Viscondessa do café, provavelmente, porque tinha consciência de que a sua riqueza dependia da prosperidade desse produto, em que o cultivo estava submetido às intempéries da natureza. Chuva e café estão constantemente associados nos seus registros: "[...] o dia esteve bom mas à noite choveu um pouco. Pagou-se aos pretos dinheiro do café 840,00" (VISCONDESSA DE ARCOZELO, 1887). 
Cabe ressaltar que os meses de chuva eram, preferencialmente, aqueles do plantio do café, com o solo úmido, tendo-se como ideais os dias encobertos ou com chuviscos leves. Dessa forma, a Viscondessa, conhecedora desse ciclo da lavoura do café, demonstra, em seus escritos, que acompanhava, incessantemente, esse processo, registrando quando chovia muito e o café poderia ser prejudicado, assim como as secas e estiagens.

Escreve ela, referindo-se ao mês de janeiro, em pleno verão, quando as chuvas aumentavam, "[...] de tarde houve uma trovoada medonha". A estiagem, por sua vez, também era outro motivo de preocupação: "[...] de tarde choveu pouco, mal apagou o pó [...]", ou "[...] a seca continua, faz medo tudo seco" (VISCONDESSA DE ARCOZELO, 1887, s/p.). Pode se deduzir que, olhando para o firmamento, a Viscondessa vigiava as condições do tempo, de manhã à noite, como quem sabe exatamente da sua impotência diante da salvaguarda de seu patrimônio.

Mas que medo era esse que a Viscondessa sentia a ponto de levá-la a retornar ao seu diário e registrar, ainda no mesmo dia quando previu a estiagem, que "Graças a Deus está chovendo bastante" IVISCONDESSA DE ARCOZELO, 1887, s/p.). Parece, mais do que se poderia supor, que a Viscondessa tinha conhecimento com exatidão das condições necessárias para o plantio, a colheita e o ensacamento do café, demonstrando a sua atenção a esses procedimentos, em diversos momentos de suas anotações: "[...] o Domingos ensacou o café hoje", ou "[...] Principiou-se a colheita do café das águas" (VISCONDESSA DE ARCOZELO, 1887, s/p.). Mais ainda, seus registros relativos ao tempo e ao café, por vezes, demonstram sua consciência da instabilidade dos resultados da lavoura, da qual dependia toda a família. Em setembro ela escreve,

As 11 horas da noite principiou a trovejar, e em seguida veio uma forte chuva de pedras e ventos que parecia que ia acabar o mundo. Foi uma coisa medonha. Estragou muito café ditou todo a baixo. prejuízo é muito grande. Na Freguezia tão bem choveu bem, e caiu alguma pedra. Na Piedade choveu mas não caiu pedra (VISCONDESSA DE ARCOZELO, 1887, s/p.).

$[\ldots]$

A chuva da noite passada deo muito prejuízo hoje é que se vio o que ela fez. Principiou-se a plantar milho nas 3 fazendas (VISCONDESSA DE ARCOZELO, 1887, s/p.). 


\section{$[\ldots]$}

C Castro e Francisquinho foram ver os estragos da chuva de pedras. Foi muito grande o estrago das pedras toda a lavoura daqui sofreo muito (VISCONDESSA DE ARCOZELO, 1887, s/p.).

Nos dias seguintes às tempestades, a Viscondessa fala das visitas em sua casa, que eram muitas, das idas e vindas entre suas três fazendas, das doenças de parentes, agregados e dos próprios escravos, do colégio dos filhos, entre outros assuntos, mas não deixa de registrar, diariamente, as condições do tempo. Segundo ela, em 28 de outubro, o tempo continuava "embrulhado."

Inegável é que o café fazia parte desse cotidiano e a Viscondessa revela a sua prioridade entre todos os afazeres dos escravos da casa, quando escreve, logo depois das chuvas devastadoras de setembro, "[...] o Castro mandou vir a gente da Piedade para apanhar café aqui. Mandei 6 raparigas e os dous cosinheiros apanhar café". Atordoada com a ameaça da chuva, a Viscondessa escreve, três dias depois desse começo da colheita, "[...] as 9 1/2 ameaçou muita chuva, veio toda a gente da roça recolher café. Choveo bastante mas passou" (VISCONDESSA DE ARCOZELO, 1887, s/p.).

Sabedora da necessidade de boas colheitas para a manutenção de suas fazendas e bens, a Viscondessa também registra as suas alegrias com os resultados que, surpreendentemente, para uma mulher do século XIX, ela parece entender com exatidão: "[...] ficarão hoje colhidos na Freguezia 3 mil cento e 58 alqueires de café" (VISCONDESSA DE ARCOZELO, 1887, s/p.). Também parece ter conhecimento da extrema necessidade do trabalho escravo e da estratégia de estimulá-los, quando diz "[...] os pretos fizeram hoje uma bonita colheita de café 592 alqueires [...]", ou ainda, "[...] o Castro disse aos pretos que os que apanhase de 6 alqueires de café para cima recebião $300 \$$ por alqueire". Em 3 de dezembro, ela anota: "[...] concluiu-se hoje a colheita de café 28 mil alqueires" (VISCONDESSA DE ARCOZELO, 1887, s/p.).

Não obstante a satisfação implícita demonstrada com os resultados da colheita, adiante, em 8 de dezembro, revela-se outra, entre as suas preocupações concernentes ao patrimônio da família, "[... ] o Castro foi ao Refugio e deo lá um grande roubo de café, mas não sabemos quem foram os ladrões". Nos dias seguintes, acompanha a investigação sobre o roubo anotando, "[...] - Castro foi as Pedras Ruivas ver se sabe alguma cousa do roubo [...]" e ainda, 
no mesmo dia, "[...] por ora não se sabe do roubo do café $[. .$.$] ". Mais tarde, a$ Viscondessa acrescenta em seu diário, "[...] o café que se encontrou escondido 11 1/2" (VISCONDESSA DE ARCOZELO, 1887, s/p.). Tais anotações denotam que ela escrevia em diferentes momentos de um mesmo dia, ou, talvez, sempre que julgasse que alguma informação era importante para registro.

Diante das aflições da Viscondessa, ainda que algumas análises não indiquem isso, é plausível concluir que ela compartilhava de diversos interesses do marido relativos aos negócios da família, possivelmente, não apenas acatando as decisões tomadas, mas, por vezes, influenciando-as. Esse poder de decisão pode ser percebido quando ela usa, recorrentemente, expressões como "mandei", "recebi", "fiz", demonstrando que, naquilo referente às casas das fazendas e a sua escravaria doméstica, era ela quem determinava as ações, revelando aspectos da educação recebida para exercer o papel social a que estava destinada.

\section{O desafio à educação das mulheres oitocentistas: a Viscondessa e sua herança}

Quando o Visconde de Arcozelo morre, em 1891, vítima de febre amarela (CASTRO, 2004), a Viscondessa terá que dar conta de outras funções, até então, não desempenhadas por ela. Terá que administrar o espólio, bem como as dívidas da família que culminaram com o pedido de liquidação da Casa Comissária de Café, da qual seu filho Ernesto era sócio, em 1893.

Visconde de Arcozello tinha, ao morrer, um monte-mor de 571:999\$500 que correspondia às fazendas: Monte Alegre, Freguesia, Piedade, Manga Larga, sítios: Santa Thereza, Cachoeira. Prédios no Rio de Janeiro, terrenos em Iguaçu, bens em Portugal, ações de Companhias, dívidas ativas. Os filhos receberam 55:947\$099. A situação financeira do Visconde, porém, não era tão boa quanto parecia. Em seu inventário, sua esposa pediu ao juiz dos órfãos, permissão para fazer um empréstimo de 130:000\$000 por 6 meses a juros de 10\% com o Banco do Brasil, a fim de cobrir as dívidas que seu falecido esposo havia contraído com um sócio em duas firmas de intermediação (MUNIZ, 2005, p. 128). 
Como inventariante do esposo, somente uma mulher "educada" poderia ser capaz de arcar com tamanha responsabilidade, considerando-se ainda as inúmeras dificuldades presentes naquele tempo e contexto, já existentes em relação aos homens, e que se exacerbavam quando se tratava de uma mulher. O inventário dá uma idéia de quão difícil foi a tarefa da Viscondessa após a morte do marido, somando-se a isso o fato de que o país acabava de abolir a escravidão e proclamar a república. $\bigcirc$ mundo que a Viscondessa conhecia e em que foi educada para viver, pouco a pouco, desmoronava-se. Um exemplo disso é o trecho do inventário citado por Muniz:

A Viscondessa de Arcozello, inventariante do casal, [...] vem solicitar-vos autorização para um empréstimo que se destina à satisfação de compromissos urgentes assumidos pelo finado. $\bigcirc$ Banco do Brasil empresta ao casal a importância de 130:000\$000 necessária para o pagamento das dívidas existentes, a juros de $10 \%$ ao ano e prazo de 6 meses. A referida soma entrará imediatamente em movimento de conta corrente [...]. Vassouras, 31 de outubro de 1891 (MUNIZ, 2005, p. 129).

Segundo Muniz (2005, p. 129), em novembro de 1892, as dívidas 120 totais da Viscondessa chegavam a $214: 000 \$ 000$, "[...] ela não conseguiu negociar com o banco e conseguiu, através de um capitalista, um adiantamento de 150:000\$000 por três meses a 10\% de juros mediante a hipoteca de uma propriedade urbana no Rio de Janeiro".

Progressivamente, a fortuna dos Viscondes de Arcozelo, que remontava às propriedades do Barão de Pati do Alferes, vai sendo dizimada. Nem os filhos, nem a Viscondessa puderam manter a patrimônio da família.

Embora a Viscondessa fosse uma mulher cuja forma de gerir a casa destoava da maioria das mulheres do seu tempo, com uma escrita cotidiana minuciosa de seus pertences, registrando a contabilidade de seus gastos pessoais desde as mais ínfimas somas gastas com um jantar no hotel: "[...] hoje não sai mandei vir o jantar do Otel custou 6.600 [...]" IVISCONDESSA DE ARCOZELO, 1887, s/p.l, até a elaboração de listas que enumeravam suas costuras, louças, e mesmo seus escravos cativos e ingênuos, além de revelar-se preocupada com a "matemática" dos custos referentes à manutenção de suas propriedades, como demonstram os seus escritos em diversos momentos, não foi possível para ela debelar o comumente destino das viúvas do século XIX. 
Corrobora tal destino, o editorial do jornal $O$ sexo feminino escrito pela redatora, Francisca Senhorinha da Motta Diniz, publicado em 7 de setembro de 1873, em um artigo intitulado A educação da mulher, que oferece algumas pistas sobre o desamparo das mulheres, sem instrução suficiente para gerir o patrimônio herdado:

Em vez de paes de família mandarem ensinar suas filhas a coser, engomar, lavar, cosinhar, varrer a casa etc., etc., mandem-thes ensinar a ler, escrever, contar, grammatica da língua nacional perfeitamente, e depois, economia e medicina doméstica, a puericultura, a litteratura (ao menos a nacional e portugueza), philosophia, a historia, a geografia, a physica, a chimica, a historia natural, para coroar esses estudos a instrucção moral e religiosa; que estas meninas assim educadas não dirão quando moças estas tristes palavras: 'Si meu pai, minha mãi, meu irmão, meu marido morrerem o que será de mim!!'(DINIZ, 1873, p. 2).6

Ainda que a educação da Viscondessa tenha sido, provavelmente, esmerada para os padrões da época, utilizando-se a forma mais recorrente pela qual as elites educavam seus filhos e filhas, ou seja, a educação doméstica, por meio da contratação de preceptoras estrangeiras, tidas como as mais aptas para educar as mulheres para a "boa sociedade" que pretendia copiar os modelos europeus (VASCONCELOS, 2005; 2007; 2013), as circunstâncias não favoreceram as suas habilidades e capacidades como gestora de suas fazendas e, mesmo com a ajuda dos filhos, também inicialmente educados por uma preceptora, tratada por "D. Sarah" e citada muitas vezes ao longo do Diário de Lembranças, o patrimônio da família pereceu.

Cabe ressaltar que a educação dada pelas preceptoras não era a garantia de nada além de saber comportar-se diante do marido e das visitas, tocar piano, bordar, coser, marcar, cortar, dançar, trabalhos de agulha, caia a ouro, prata, matiz e escama de peixe, tricot, filot, flores, obras de fantasia, recortar estofos, veludos e outros trabalhos manuais, falar francês e ter noções básicas para a condução da casa e a educação dos filhos (VASCONCELOS, 2011 ). Poucas meninas, bem como suas famílias, tinham interesse em aprender matérias como lógica, matemática, geometria, aritmética, álgebra, contabilidade, escrituração mercantil, física, botânica, história universal, história do Brasil, geografia, desenho, pintura e aquarela, considerados conhecimentos masculinos. A "boa" educação feminina caracterizava-se como o ensino da 
escrita, leitura e contas (para a contabilidade doméstica), ensinamentos de português e francês prioritariamente, seguidos de caligrafia, literatura, composição, religião, música, piano, solfejo, canto, gramática portuguesa, latina e francesa (MENDONÇA; VASCONCELOS, 2011 ).

Não se tem registro de quem terá sido a preceptora da Viscondessa de Arcozelo, responsável por sua educação e, em que pese o seu temperamento, aquela que a terá influenciado na organização e cuidado com toda a administração doméstica. Mas Maria Werneck de Castro (2004), a neta, oferece alguma pista, quando escreve sobre a preceptora contratada por sua outra avó, Carolina de Avelar Albuquerque que, segundo a autora,

[...] fez tudo para educar as filhas, sendo ela própria pouco instruída, se bem que para a época escrevesse direitinho, com boa caligrafia. Prova desse cuidado é que tomou uma governante francesa, mademoiselle Régine, para ensinar às meninas algumas letras, francês, piano e bonnes manières (CASTRO, 2004, p. 34).

A neta destaca ainda a diferença entre as avós. Enquanto Maria Isabel é descrita como "[...] boa administradora do patrimônio da família, 122 que então contava com três fazendas (Monte Alegre, Freguesia e Piedade) e numerosos outros bens, inclusive escravos [...]", a avó Carolina é apresentada como alguém que "[...] nada entendia de terras e lavoura [...]" (CASTRO, 2004, p. 33 e 105), entregando a administração de seus bens ao irmão. $\mathrm{Na}$ diferença entre a personalidade das avós, revela-se a própria singularidade da Viscondessa de Arcozelo, pois grande parte das mulheres de elite no oitocentos estava totalmente alijada de qualquer assunto que não se referisse, estritamente, aos afazeres da casa. Todavia, os predicados reconhecidos na Viscondessa e a sua educação esmerada não foram suficientes para conservar seu patrimônio.

Na falta de preparação para administrar ou prover o próprio sustento contribuía a exclusiva aspiração pelo casamento, das mulheres do século XIX. Casar era a principal e a única função considerada adequada ao sexo feminino e, assim, desde a mais tenra idade, a preocupação das famílias de elite e das próprias mulheres era arranjar um "bom casamento". Esse conceito de bom casamento remete, especialmente, a um homem cujas posses fossem suficientes para os luxos a que estavam habituadas na casa de seus pais, e a garantia de que seus dias seriam conduzidos por alguém que as pouparia 
de todas as preocupações relativas ao sustento e ao patrimônio da família (VASCONCELOS, 2013).

Em janeiro de 1881, no jornal A mãi de família7, o redator Dr. Carlos Costa, preocupado com o excesso de casamentos precoces que ocorriam, escrevia sobre as moléstias que impedem o casamento e também aquelas causadas por serem as noivas muito jovens. O médico não se referia, apenas, a doenças, mas também fazia veementes críticas ao hábito de casar as moças muito cedo, aos 13 anos principalmente, quando as mesmas não teriam o completo desenvolvimento dos órgãos e nem condições de se submeterem aos "elevados e difíceis encargos da maternidade". Aos pais era sugerido, então, que "[...] tudo fizessem para afastar a ideia de casamento do espírito de suas filhas antes dos 18 a 20 anos [...]", mesmo que thes parecesse muito tempo e muito difícil de manter tal decisão (A MÃI DE FAMÍlIA, 1880, p. 2).

Cruzando as informações de Muniz (2005, p. 126), que afirma o casamento da Viscondessa com o médico português das fazendas de seu pai, Joaquim Teixeira de Castro, entre os anos de 1860 e 1861, e as narrativas da neta Maria Werneck de Castro (2004, p. 102), que assinala o nascimento da Viscondessa em 1840, provavelmente, Maria Isabel de Lacerda Werneck já tivesse 20 anos quando se casou, idade considerada, na época, elevada para se conseguir um casamento. Isso, talvez, explique a permissão do Barão de Pati do Alferes ao casamento de sua herdeira com um forasteiro que, ao chegar as suas fazendas para exercer a função de médico, portava apenas, a julgar por sua imagem retratada, a bela figura, como sugere Muniz:

Joaquim Teixeira de Castro nasceu em 1825 na Freguesia de Arcozello no Porto. Chegou ao Brasil na década de 40 (1848/1849), formado em Medicina. Tendo contato com Francisco Peixoto de Lacerda Werneck foi convidado, por ele, para se tornar médico em suas fazendas em Pati do Alferes. Em 1850, seu nome já saía no Almanack Laemmert como médico, porém, sem o título de Doutor. Existiam dúvidas se Joaquim era realmente médico, por não ter seu diploma revalidado na Escola de Medicina do Rio de Janeiro. Alguns livros de historiadores locais diziam que ele havia estudado direito, outros, farmácia, mas não medicina. Em 1853, ele foi interpelado por uma Comissão da Câmara de Vassouras, que pedia a apresentação de seu diploma de medicina. ${ }^{8}$ Joaquim responde à Câmara em uma carta datada de 11 de março de 1853, em que dizia: 'Sou formado pela Escola Médico-Cirúrgica do Porto e apresento meu diploma para ser visto 
e registrado. Ao chegar ao Brasil não fiz o exame de suficiência perante a Escola de Medicina do Rio de Janeiro. Sou médico particular e exclusivo das fazendas do Barão de Paty do Alferes, não me ocupando de clínicas fora delas... ${ }^{19}$. [...] Na década de 60, Joaquim casou-se com Maria Isabel de Lacerda Werneck, filha do Barão de Paty, recebendo dote como era costume na época. $\bigcirc$ Barão de Paty faleceu em 1862, recebendo, Joaquim e Maria Isabel, uma herança de 62:005\$120. ${ }^{10}$ Pela herança tornou-se proprietário da Fazenda Monte Alegre com todos os seus pertences, terras, café, 131 escravos. A Fazenda Manga Larga com 74 escravos, animais, gado, móveis, terras e cafezais. A Fazenda Palmeiras com casa de negócio e moradia, benfeitorias, 10.000 pés de café, 86,25 alqueires (MUNIZ, 2005, p. 126).

A Viscondessa não teve filhas mulheres, mas, mesmo para a educação dos filhos, como era costume entre as famílias de elite, tratou de utilizar-se dos serviços de uma preceptora portuguesa, D. Sarah, a qual, infelizmente, não é minuciosamente descrita no Diário de Lembranças. Contudo, é possível entender a "governante", observando-se muitas outras anunciadas pelos jornais da época, que ofereciam seus serviços para educar crianças em fazendas da

124 Província do Rio de Janeiro. Da mesma forma, também os fazendeiros buscavam mulheres, "cheias de qualidades", para trabalhar como preceptoras, na esperança de que fossem capazes de agregar valor a principal função de suas filhas mulheres: realizar um bom casamento (VASCONCELOS, 2011 ).

Nessa perspectiva, os jornais sugerem uma infinidade de anúncios de um ofício que parece ter sido o único apropriado, durante o século XIX, a mulheres educadas, mas que não tinham parentela para sustentá-las e precisavam prover a sua própria existência, situação considerada de extrema infelicidade para mulheres cujo maior desejo era casar, ter filhos e governar a própria casa (VASCONCELOS, 2011 ).

A preceptora dos filhos da Viscondessa de Arcozelo, D. Sarah, é o protótipo das preceptoras de seu tempo, portuguesa vinda para o Brasil, empregou-se na casa dos Viscondes, acompanhando a família nas diversas ocasiões, desde missas a passeios, e em todas as atividades da parentela. D. Sarah é ainda mencionada em uma passagem bastante significativa do Diário de Lembranças, quando o Visconde resolve dispensar os seus serviços para mandar os filhos à escola. Pelo que se percebe, a Viscondessa não discute a decisão do marido, mas isso não a impede que registre a sua consternação 
com a partida da preceptora: "O Castro falou hoje com D. Sarah que não queria continuar com os meninos estudando em casa e que irão para o collégio. Ella disse que nesse caso se retirava para o Rio". Sete dias depois, é registrada a partida da preceptora "[...] partio D. Sarah as 5 1/2 tive muita pena della" (VISCONDESSA DE ARCOZELO, 1887, s/p.).

$\bigcirc$ crescimento do número de colégios que ocorre, nas últimas décadas do século XIX, acaba por seduzir as elites para uma possibilidade de educação coletiva que, fora da casa, segundo seus propagandistas, permitiria a formação dos sujeitos para enfrentar os desafios do século XX, que se anunciava. Tal fato pode ser constatado pelos variados anúncios, presentes no cabeçalho das páginas do Diário da Viscondessa, nos quais, entre roupas, enfeites, artigos de luxo, instrumentos musicais, máquinas de costura, remédios, materiais para escrever e copiar, álbuns e retratos, ofereciam-se internatos, semi-internatos e externatos.

Além disso, suspeitava-se que, por meio da escolaridade, os jovens estariam mais aptos aos ideais republicanos que se avizinhavam, cada vez com mais intensidade. Ou seja, sem muita clareza, já se supunha que algo estava para mudar também nas relações educacionais. Em um mundo que se transformava em diferentes aspectos, e a educação era um deles, conjeturava-se que, brevemente, poderia se estabelecer a hegemonia da escola, delimitando, cada vez mais, o campo de ação da centenária casa-grande, na qual, até então, se faziam todos os rituais desde batizar, rezar, aprender, casar, até enterrar (MENDONÇA; VASCONCELOS, 201 1). Todavia, contemporâneas da Viscondessa, poucas mulheres devem ter tido outra possibilidade educativa que não tenha sido na própria casa.

\section{A imagem e a escrita: considerações finais}

Olhando para a fotografia ritual da Viscondessa de Arcozelo, aquela que, ao lado da do marido, com uma moldura ovalada, fazia parte do simbolismo de uma casa nobre, percebe-se que a Viscondessa não era uma representante do padrão de beleza da época, em que pese os defeitos de uma imagem, possivelmente, captada em um período um pouco anterior ao ano quando escreveu o seu diário, datado de 1887. Por outro lado, é preciso considerar, também, que as fotografias, naquele tempo, eram feitas em estúdio 
e retocadas em alguns pontos. De toda forma, a Viscondessa parece ter um certo estrabismo que contrasta com a sua aparência produzida para aquele momento, quando não há absolutamente nada fora do lugar, nem o penteado, nem o vestido, evidenciando significativa afinidade entre os escritos detalhados e organizados do Diário de Lembranças e a imagem de sua autora.

A mulher cujas anotações pessoais quando tinha 47 anos, hoje são apresentadas por meio do seu Diário, oferece a todos os seus leitores, parte de uma história de vida que possui, por si só, os diversos elementos característicos da educação feminina do seu tempo e os desafios que trariam o devir. Maria Isabel enfrentará a década de 1890 e os primeiros anos do século XX, tentando preservar pálidos reflexos de sua existência, contada no Diário de Lembranças.

A casa do Roseiral, última morada da Viscondessa, narrada por sua neta, revela a tentativa dessa típica representante feminina do Brasil oitocentista e de suas elites, de tentar manter a todo o custo um cotidiano já esvanecido. Em uma casa descrita como muito simples, pertencendo ao filho "Francisquinho" e parecendo mais uma "casa de colono", a Viscondessa passou os últimos anos de sua vida, em um lugar conhecido como "fazendola do Roseiral" (CASTRO, 126 2004). Nas lembranças da neta, concretiza-se um pouco a imagem da Viscondessa destituída de seus bens, suas visitas, suas compras, seus escravos e escravas, suas louças, a fartura de suas casas, onde não pernoitar tratava-se de uma "desfeita" imperdoável.

Maria Werneck de Castro (2004, p. 42) conta que era "[...] uma tristeza ver aquela senhora, antes riquíssima, morando naquele casebre. Mas ela era extraordinária: nem uma queixa, nem uma lamúria" . Talvez essa não fosse apenas uma marca de personalidade "extraordinária", mas, provavelmente, se tratasse de alguém que ao olhar para o seu entorno já não reconhecia mais - lugar a que pertenceu, a arquitetura, a estética, os valores, os sentimentos e as imagens que a acompanharam durante a vida. $\bigcirc$ mundo mudava, 0 país modificava-se e as mulheres estariam cada vez mais perto daquilo que a Viscondessa poderia ter sido, caso fosse permitido a ela não apenas escrever, mas também desempenhar outros papéis.

"Atrasada" em sua morte, quando mais nada do seu passado podia ser reconhecido, a Viscondessa foi condenada a ver um outro mundo e, especialmente, a conviver unicamente com seus ex-escravos, já que foram os poucos 
que sobreviveram ao seu lado. Todavia, talvez ela tenha encontrado neles, em seus últimos anos de vida, a companhia, as visitas, as alegrias e as preocupações cotidianas que tanto preenchiam os seus dias, registrados no diário de 1887.

Como sugere Mignot (2008), ao visualizar as páginas envelhecidas do exemplar de capa verde, que, na verdade, tratava-se de um caderno denominado Diário de Lembranças, publicado por Antônio José Gomes Brandão e contendo as "365 páginas para notas diárias", é possível imaginar um pouco da vida dessa mulher, cuja trajetória se assemelha a de tantas mulheres oitocentistas.

Para o leitor, manusear as páginas escritas há mais de cem anos, observar seus timbres, seus anúncios, seus símbolos, suas marcas, suas rasuras e recortes, assim como a letra desenhada, por vezes, mais alterada, e em outras, serena e concisa, e pensar que a Viscondessa ainda viveu por décadas, adentrando o século XX, remete à indagação do que ocorreu nos anos que se sucederam: terá a Viscondessa relido o seu Diário? Terá revisto suas fazendas e seus pertences tão bem "inventariados" em seus escritos? Terá vigiado a chuva e pensado no café? Terá ela percebido as transformações que ocorreram a sua volta? Ou terá atribuído seu "destino" às infelicidades das mulheres que perdiam "cedo" seus maridos? Impossível saber. Certo é que uma mulher capaz de descrever seu cotidiano com tamanho esmero, também pudesse compreender que as suas vicissitudes não foram simples decorrências de seu protagonismo, alijadas do cenário em que ocorriam, mas, sim, circunstâncias impostas por um contexto para o qual não havia precedentes, até então.

De toda forma, entre as imensas lacunas deixadas pela falta de escritas femininas relativas ao oitocentos, como já assinalava Lejuene (1997), Maria Isabel de Lacerda Werneck conseguiu, com seu Diário de Lembranças, eternizar um passado cristalizado em suas anotações que, entre tantos outros aspectos, revela aos leitores do século XXI, características de uma mulher educada "no" e "para" o oitocentos. 


\section{Notas}

1 Museu Imperial de Petrópolis - Registrado sob o códice DM I- 15.

2 Neste artigo é utilizado o título "Viscondessa de Arcozelo" diferentemente das autoras citadas, tomando como referência a assinatura da própria Viscondessa em um recibo da época, digitalizado no livro de CASTRO, Maria Werneck de. No tempo dos barões: histórias do apogeu e decadência de uma família fluminense no ciclo do café. Rio de janeiro: Bem-Te-Vi, 2004, p. 173.

3 Conforme Castro (2004, p. 11 8-1 19): "É difícil entender como a fortuna do barão de Pati de Alferes [pai da Viscondessa de Arcozelo], com sete fazendas e a certa altura com, dizia-se, mil escravos, pôde se esfarelar tão rapidamente".

4 As citações estão mantidas no idioma original do texto referendado.

5 Cf. Muniz (2005, p. 129), a data é 1876, considerando o documento constante na Torre do Tombo, Portugal. Processo de Justificação de Nobreza (Maço 64, n. 20, 1876).

$6 \bigcirc$ jornal $\bigcirc$ sexo feminino foi publicado originalmente em 1873, na cidade de Campanha, em Minas Gerais, tendo como proprietária e redatora Francisca Senhorinha da Motta Diniz. Alguns anos mais tarde a proprietária mudou-se para a Corte e continuou a publicar um periódico com o mesmo nome na cidade do Rio de Janeiro.

7 A mãi de família: Jornal Scientifico Litterario e Illustrado, editado pelo Dr. Carlos Costa, um médico com grande clientela na Corte Imperial, pretendia dar um estatuto de cientificidade ao cotidiano das famílias, introduzindo o pensamento higienista, Rio de Janeiro, n. 7, p. 53, mar. 1880.

1288 Cf. Muniz (2005, p. 126): "Rodrigues Filho, Irinea Lobo, Di Palma Margareth, Di Palma Elizabeth: Visconde de Arcozelo. Série Pequenas Biografias Fluminenses. Instituto de Arquivologia Histórica do Médio Paraíba (IAHMP)".

9 Cf. Muniz, (2005), A.M.V. Casa da Hera, Correspondência recebida de altas autoridades, 1853

10 Cf. Muniz, (2005), C. $1^{\circ}$ O. V. - CDH - Cx. 115 - Inventário do Barão de Paty do Alferes, 1862.

\section{Referências}

A MAI de família. Jornal Scientifico Litterario e Ilustrado, Rio de Janeiro, p. 1-2, jan./dez. 1879.

A MAI de familia. Jornal Scientifico Litterario e Ilustrado, Rio de Janeiro, p. 1-2, jan./dez. 1888.

BARBALATO, Beatrice. O ethos e o tempo. In: VASCONCELOS, Maria Celi Chaves; CORDEIRO, Verbena Maria Rocha; VICENTINI, Paula Perin (Org.). (Auto) biografia, literatura e história. Curitiba: CRV, 2014. 
CASTRO, Maria Werneck de. No tempo dos barões: histórias do apogeu e decadência de uma família fluminense no ciclo do café. Rio de Janeiro: Bem-Te-Vi, 2004.

CUNHA, Maria Teresa. Diários pessoais. Territórios abertos para a história. In: PINSKY, Carla Bassanezi; LUCA, Tania Regina de (Org.). O historiador e suas fontes. São Paulo: Contexto, 2011.

CUNHA, Maria Teresa. Diários íntimos de professoras: letras que duram. In: MIGNOT, Ana Chrystina Venancio; BASTOS, Maria Helena Camara; CUNHA, Maria Teresa Santos (Org.). Refúgios do eu. Educação, história, escrita autobiográfica. Florianópolis: Mulheres, 2000.

DINIZ. Francisca Senhorinha da Motta. A educação da mulher. O sexo feminino. Rio de Janeiro, v. 1, n. 1, p. 1-2, 1873.

GILLIES, Ana Maria Rufino. Uma imigrante britânica no Paraná na segunda metade do século XIX: na escrita de seu diário, memória, história e representação de si. Diálogos, Maringá, v. 17, n. 1, p. 227-253, jan./abri. 2013. Disponível em: http://www.redalyc.org/articulo. oa? id=305528853009. Acesso em: 10 jun. 2014.

GÓMEZ, Antonio Castillo. Aquí lo hallarán con toda verdad. Diarios personales en la España del Siglo de Oro. In: VASCONCELOS, Maria Celi Chaves; CORDEIRO, Verbena Maria Rocha; VICENTINII, Paula Perin (Org.). (Auto) biografia, literatura e história. Curitiba: CRV, 2014.

LEJEUNE, Philippe. Diários de garotas francesas no século XIX: constituição e transgressão de um gênero literário. Cadernos Pagu, Campinas, n. 8/9, 1997, p. 99-1 14. Disponível em: www. bibliotecadigital. unicamp.br/document/?down=51147. Acesso em: 12 jun. 2014.

MALTA, Marize. O olhar decorativo: ambientes domésticos em fins do século XIX no Rio de Janeiro. Rio de Janeiro: Mauad X, 2011.

MAUAD, Ana Maria; MUAZE, Mariana. A escrita da intimidade: história e memória no diário da viscondessa do Arcozelo. In: GOMES, Angela de Castro (Org.). Escrita de si. Escrita da história. Rio de Janeiro: Editora FGV, 2004.

MENDONÇA, Ana Waleska Pollo Campos; VASCONCELOS, Maria Celi Chaves. La Genese du concept d'education publique au Portugal et au Bresil. Paedagogica Historica, Abingdon, Oxfordshire, United Kingdom, v. 47, n. 1-2, p. 49-63, fév. 2011.

MIGNOT, Ana Chrystina Venancio (Org.). Cadernos à vista: escola, memória e cultura escrita. Rio de Janeiro: Edveri, 2008. 
MUNIZ, Célia Maria Loureiro. A riqueza fugaz: trajetórias e estratégias de famílias de proprietários de terras de Vassouras, 1820-1890. 2005. 257f. Tese (Doutorado em História Social) - Programa de Pós-Graduação em História Social, Universidade Federal do Rio de Janeiro. Rio de Janeiro, 2005.

NORA, Pierre. Ensaios de ego-história. Lisboa: Edições 70, 1987.

SENNA, Ernesto. O velho comércio do Rio de Janeiro. Reedição de G. Ermakoff Casa Editorial, Rio de Janeiro, 2006. (Rio de Janeiro: Livraria Granier, 1910).

VASCONCELOS, Maria Celi Chaves. A casa e seus mestres: a educação no Brasil de oitocentos. Rio de Janeiro: Gryphus, 2005.

A educação doméstica no Brasil de oitocentos. Revista Educação em Questão, Natal, v. 28, n. 14, p. 24-41, jan./jun. 2007.

Mulheres preceptoras no Brasil oitocentista: gênero, sistema social e educação feminina. In: FRANCO, Sebastião Pimente; PALHARES SÁ, Nicanor (Org.). Gênero, etnia e movimentos sociais na história da educação. Vitória: Edufes, 2011.

Domestic Education in Nineteenth Century Brazil: Aspects of european influence on the performance of tutors and private teachers. Revista HSE - Social and Education History, Hipatia Press, Barcelona, v. 2, p. 1-22, 2013.

A escrita cotidiana no Diário de Lembranças da Viscondessa de Arcozelo: fragmentos (auto) biográficos de um egodocumento. In: VASCONCELOS, Maria Celi Chaves; CORDEIRO, Verbena Maria Rocha; VICENTINI, Paula Perin (Org.). (Auto) biografia, literatura e história. Curitiba: CRV, 2014.

VISCONDESSA DO ARCOZELO. Diário de lembranças. Rio de Janeiro, 1887. (Publicado por Antônio José Gomes Brandão. Relativo ao ano de 1887).

Maria Celi Chaves Vasconcelos

Universidade do Estado do Rio de Janeiro | Ueri

Faculdade de Educação da Universidade do Estado do Rio de Janeiro

Programa de Pós-Graduação em Educação | Uerj

Grupo de Pesquisa História e Memória das Políticas Educacionais no Território

Fluminense 
Pesquisadora do CNPq E-mail | maria2.celi@gmail.com

Recebido 21 ago. 2015 Aceito 26 out. 2015 